\title{
VIRUSURI RESPIRATORII NOI ÎN INFECT,IILE DE TRACT RESPIRATOR INFERIOR LA COPIL: PROFILURI CLINICE ŞI EPIDEMIOLOGICE
}

\author{
Asist. Univ. Dr. Alexandru-Ioan Ulmeanu, Şef Lucr. Dr. Carmen Zăpucioiu, \\ Prof. Dr. Coriolan-Emil Ulmeanu \\ Catedra Pediatrie, Spitalul Clinic de Urgență pentru Copii ,, Grigore Alexandrescu“", \\ Universitatea de Medicină şi Farmacie „, Carol Davila“, Bucureşti
}

\begin{abstract}
REZUMAT
Infecțíle virale de tract respirator reprezintă una din cauzele principale de morbiditate şi mortalitate în patologia pediatrică. Autorii aduc informații de ultima oră privind structura, mecanismele patogenetice, caracteristicile clinice, epidemiologice şi răspunsul la tratament a unor virusuri descoperite recent care afectează tractul respirator la copil: bocavirusul, metapneumovirusul, coronavirusurile şi rinovirusul C.

Cuvinte cheie: bocavirus, metapneumovirus, coronavirus, rhinovirus C, pneumonie, bronşiolită
\end{abstract}

\section{INTRODUCERE}

Infecțiile virale de tract respirator inferior reprezintă o cauză importantă de morbiditate şi mortalitate în patologia pediatrică. În lume se înregistrează în fiecare an, în populația pediatrică, aproximativ 100 de milioane de cazuri de pneumonie virală, ele reprezentând $60 \%$ din infecțiile de tract respirator inferior (ITRI) ale copilului. Virusurile cel mai frecvent implicate în ITRI sunt virusul sinciţial respirator (VSR), rinovirusul, metapneumovirusul (hMPV), bocavirusul (HBoV) şi virusul parainfluenzae, acestea pot fi diagnosticate izolat sau în cadrul coinfecțiilor virale. 30\% dintre copii cu pneumonie virală au semne de suprainfecție bacteriană în momentul diagnosticului (1). Pe lângă virusurile foarte cunoscute implicate în ITRI ale copilului, în literatură au apărut informații importante şi de mare actualitate despre caracteristicile clinice şi epidemiologice ale virusurilor mai noi descoperite ce afectează tractul respirator al copilului: bocavirusul, metapneumovirusul, coronavirusurile şi rinovirusul C.

\section{BOCAVIRUSUL}

Bocavirusul (HBoV) este un virus descris recent, descoperit în anul 2005 în aspiratele nazofaringiene ale copiilor din Suedia. Prevalența sa este de aproximativ 10\% global şi este implicat frecvent în infecții de căi respiratorii superioare şi inferioare la copil, ce pot îmbrăca forme severe mai ales la copii prematuri. El este unul din cele mai frecvent detectate virusuri respiratorii sub vârsta de 5 ani, cu un maxim de frecvență între 6 şi 24 luni. Prevalența sa în populația adultă este foarte redusă. $(2,3)$

\section{Structura virală}

Bocavirusul face parte din familia Parvoviridae, sub familia Parvovirinae, genul Bocavirus. Este un virus mic icosaedric, fără anvelopa, cu genom $\mathrm{ADN}$, linear, monocatenar. Capsida este alcătuită din două proteine virale VP1 şi VP2 şi este foarte asemănătoare parvovirusului B19 (4). Există descrise în acest moment patru specii de bocavirus: HBoV1, HBoV2, HboV3, HboV4. Primul subtip este implicat în infecțiile de tract respirator, însă poate fi 
izolat şi din materiile fecale, în timp ce ultimele trei au fost izolate mai ales din scaun.

\section{Mod de transmitere}

Bocavirusul este un virus ubicuitar al cărui mod transmitere este asemănător parvovirusurilor, prin inhalarea picăturilor mici din aer sau prin contact cu secreții infectate. Majoritatea studiilor arată ca infecția cu BoV are loc pe tot timpul anului, cu vârfuri de incidență iarna şi primăvara. $(5,6)$. Majoritatea copiilor sunt infectați până la 6 ani, anticorpii formați sunt orientați împotriva capsidei, iar datorită lipsei de variație a învelişului viral, aceştia probabil asigură protecție pentru toată viața. Adulții au cel mai frecvent anticorpi prezenți, aceasta demonstrând că infecția este mai frecventă în copilărie $(7,8)$.

\section{Patogenie}

Infecția cu bocavirus duce la distrugerea epiteliului aparatului respirator prin afectarea joncțiunilor celulare strânse, cu pierderea cililor şi hipertrofia celulelor epiteliale (9). În timpul infecției acute ADN-HboV şi IgM anti $\mathrm{HboV}$ pot fi detectate în ser, fapt care sugerează prezența infecției sistemice. Infecția virală induce un răspuns imun de tip viral ce implică secreția de citokine prin intermediul Th1 şi Th2. Virusul poate persista foarte mult timp în organism, chiar 4-5 luni, cel mai probabil prin replicare şi eliminare persistentă. Această persistență prelungită ar putea explica frecvența mare cu care acest virus este implicat în coinfecțiile virale. $(10,11)$

\section{Manifestări clinice şi paraclinice}

Studiile din literatură au raportat asocieri ale HboV cu infecții respiratorii de tip: rinofaringită acută, wheezing indus viral, astm, bronşiolită acută, pneumonie sau otită medie acută. (12). În ordinea frecvenței, tusea, febra, rinoreea, polipneea şi wheezingul au reprezentat semnele şi simptomele cel mai frecvent întâlnite. $\mathrm{Cu}$ frecvență redusă au fost făcute asocieri cu: diareea acută, conjunctivita acută, vărsăturile sau rashul. Apariţia şi severitatea simptomatologiei a fost asociată cu niveluri crescute ale viremiei $(2,13)$. Infecțiile cu alte virusuri nu au putut fi diferențiate clinic de infecția cu bocavirus, totuşi s-a constatat că hipoxia şi neutrofilia se asociază mai frecvent infecției cu hBoV față de infecția cu VSR. (12). Paraclinic, numărul de leucocite a fost normal, cu probe inflamatorii în limite normale, însă cu apariția neutrofiliei. (14) Radiologic, aspectul cel mai frecvent întâlnit a fost de pneu- monie acută interstițială cu opacități lineare şi micronodulare situate perihilar bilateral, hiperinflație pulmonară bilaterală şi atelectazie. Nu există aspecte patognomonice (12).

\section{Diagnosticul}

Majoritatea studiilor au folosit pentru diagnostic metoda PCR, însă această determinare are ca limitare imposibilitatea excluderii infecției vechi şi persistente. Astfel, pentru a stabili diagnosticul cu precizie este nevoie de determinarea ADN-HboV din ser împreună cu prezența anticorpilor de tip IgM din ser, sau creşterea în dinamică de 4 ori a titrurilor de anticorpi de tip IgG împreună cu prezența simptomatologiei (2). Au fost asociate pozitiv cu infecția virală certă: monoinfecția, încărcătura virală la niveluri înalte şi prezența viremiei. Având în vedere că în practică determinările de anticorpi sau de viremie sunt greu de efectuat, se consideră un diagnostic de certitudine determinarea PCR de $\mathrm{HboV} \mathrm{cu}>10^{4}$ genomi $/ \mathrm{ml}$.

\section{Tratament}

Infecțiile de tract respirator inferior cu bocavirus sunt infecții virale autolimitate şi de obicei necomplicate, ce necesită doar tratament suportiv. Prednisolonul nu s-a dovedit eficient într-un studiu efectuat pe un grup de copii cu wheezing şi infecţie cu bocavirus $(15,16)$.

\section{METAPNEUMOVIRUSUL (HMPV)}

Este un virus descoperit relativ recent, în anul 2001 de o echipă de cercetători din Olanda, la un grup de copii cu boli respiratorii acute, aceştia prezentând de la simple rinofaringite la bronşiolite şi pneumonii severe. Studiile din literatură sugerează însă că HMPV a fost implicat în infecțiile acute de tract respirator de mai mult de 50 ani. Prevalența infecției cu HMPV variază în funcție de studii între 4 şi 16\% dintre pacienții cu infecție de tract respirator $(17,18)$.

\section{Structura virală}

HMPV face parte din familia Paramixoviridae, subfamilia Pneumovirinae, genul Metapneumovirus şi poate fi întâlnit sub două forme principale: HMPV tip A şi HMPV tip B. Structura sa este foarte asemănătoare VSR, acesta fiind şi el membru al subfamiliei Pneumovirinae. Virionul hMPV este pleiomorfic, cu dimensiuni variabile, este un virus anvelopat, cu genom ARN, înrudit cu MPV aviar. Comparând genomul hMPV cu cel al VSR s-a 
constatat că cele două proteine structurale NS1 şi NS2 lipsesc la MPV, lipsa acestora explicând răspunsul imunitar diferit din cadrul celor două tipuri de infecții $(18,19)$.

\section{Mod de transmitere}

Modul de transmitere cel mai frecvent este pe cale aerogenă prin picături mici sau prin contact cu secreții infectate. Incubația este scurtă, 3-5 zile (20). $\mathrm{Au}$ fost raportate şi infecții nosocomiale. Virusul este ubicuitar, are însă variație sezonieră, cu vârfuri de incidență la sfârşitul iernii şi începutul primăverii în emisfera nordică şi sfârşitul primăverii în emisfera sudică. (21) El infectează mai ales copiii, vârful de incidență este la 2 ani, majoritatea acestora fiind infectaţi până la vârsta de 5 ani, aceştia se pot reinfecta însă în perioada adultă datorită obținerii unui titru de anticorpi neprotector după prima infecție sau prin reinfecție cu genotip diferit (22). Infecția cu HMPV poate avea loc la orice vârstă, însă ea este mai severă la copii mici şi sugari, la fosti prematuri, la cei cu boli cardiace şi pulmonare cronice sau boli neuromusculare, precum şi la aceia ce au dobândit infecția în cadru spitalicesc. HMPV este des întâlnit în cadrul coinfecțiilor virale, unele studii sugerând că asocierea mai ales cu VSR creşte severitatea afecțiunii respiratorii. (18)

\section{Patogenie}

Integrina alfa-v-beta1 facilitează penetrarea celulelor epiteliului respirator (23). Infectia duce la hiperproducție de mucus, hiperplazie a epiteliului respirator şi hiperreactivitate bronşică. Hiperreactivitatea bronşică dovedită prin test de provocare la metacolină subliniază ideeea că infecțiile severe virale în copilărie pot fi asociate cu dezvoltarea ulterioară a astmului bronşic. (24)

\section{Manifestări clinice şi paraclinice}

Încărcătura virală înaltă se corelează cu prezența simptomatologiei şi în unele studii cu severitatea bolii (25). Co-infecția cu VSR a influențat severitatea bolii la copii sub 2 ani. (24)

Cele mai frecvente semne şi simptome întâlnite au fost tusea, rinoreea, febra şi wheezingul. Diagnosticele cele mai frecvent întâlnite au fost bronşiolita acută, crupul viral, exacerbarea de astm bronşic şi pneumonia. (26)

Paraclinic în stadiile inițiale ale infecției se poate constata creşterea uşoară/moderată a proteinei $\mathrm{C}$ reactive (CRP) cu monocitoză, în evoluție o dată cu ameliorarea simptomatologiei formula leucocitară se normalizează, însă CRP se poate menține crescută (18).

\section{Diagnostic}

RT-PCR reprezintă cea mai sensibilă metodă de determinare a HMPV. Tehnicile de imunofluorescență de tip dFA (direct fluorescent antibody) permit detectarea antigenului în aspiratele nazofaringiene în 2-3 ore, însă această tehnică nu este disponibilă decât în laboratoarele specializate. Diagnosticul poate fi suţinut şi pe teste serologice de tip ELISA ce pot detecta prezența anticorpilor anti proteina N. (24).

\section{Tratament}

Tratamentul este în principal suportiv, însă ribavirina a fost eficientă in vitro împotriva HMPV, ea reducând replicarea virală la şoarecii infectaţi. Ea a fost folosită cu succes împreună cu imunoglobulinele nespecifice într-un caz de infecție severă la un copil imunodeprimat aflat în tratament chimioterapic pentru limfom Burkit $(27,28)$. Au arătat efecte promițătoare în studiile efectuate pe animale de laborator anticorpii monoclonali, inhibitorii de fuziune şi siARN (molecule de ARN interferent) (18).

\section{Prevenție}

Infecția cu HMPV nu duce la instalarea unei imunităti de durată, problema principală întâlnită în conceperea unui vaccin a fost dificultatea de a obține un răspuns imun puternic şi de durată. În acest moment este în desfăşurare un studiu de fază 1 pentru a stabili eficacitatea şi siguranţa unui vaccin viu atenuat împotriva infecției cu HMPV (29). Există studii promițătoare pe animale de laborator ce arată eficiența anticorpilor monoclonali împotriva HMPV atunci când sunt administraţi atât înainte de infecție, dar şi după 48 ore de la instalarea ei. $(30,31)$

\section{CORONAVIRUSURILE}

Sunt virusuri implicate frecvent în infecțiile de tract respirator la adult, însă cu rol important şi în infectiile respiratorii de tract inferior severe ale copilului. Sunt membre ale familiei Nidovirus şi sunt împărţite în două genuri importante: alfa coronavirus ce are ca reprezentanți HCOV229E, HCOVNL63 şi beta coronavirus cu reprezentanţii HCOV HKU1 HCOV OC43 şi virusurile MERSCOV şi SARS-COV (32). Sunt virusuri anvelopate cu genom ARN ce cresc greu pe medii de cultură. Primele tulpini descoperite în anii' 60 au fost $229 \mathrm{E}$ şi OC43, iar după descoperirea SARS după anul 2002 au fost rapid descrise ultimele serotipuri NL63 şi HKU1, ce sunt ubicuitare (33). 


\section{Mod de transmitere}

Transmiterea are loc cel mai frecvent pe cale aerogenă, dar şi prin contactul cu secrețiile infectate. După infecție apare imunitate față de serotip, însă aceasta nu este de durată, reinfecția fiind posibilă. $(34,35)$

\section{Manifestările clinice}

Cele mai frecvente simptome întâlnite au fost rinoreea, tusea şi wheezingul. Pentru subtipurile 229E, OC43, NL63 şi HKU1, tabloul clinic este cel mai frecvent asemănător infecției cu rhinovirus (36). În mod particular, HCOVNL63 a fost asociat crupului viral, iar HCOV HKV1 şi OC43 au fost întâlnite la sugari ce asociază diaree şi manifestări respiratorii, dar pot fi întâlnite şi la copii asimptomatici (35). Coronavirusurile au fost izolate frecvent în secreția otică a copiilor cu otită medie acută şi au fost implicate în declanşarea crizelor severe de astm bronşic $(36,37)$. Coronavirusurile pot produce infecții nozocomiale severe. $(38,39)$. În literatură au fost descrise asocieri posibile ale infecțiilor cu HCOV cu scleroza multiplă şi boala Kawasaki. (33)

\section{Diagnostic}

Diagnosticul de certitudine al infecţiei se pune prin detectarea prin RT-PCR a virusului în aspiratul nazofaringian dar pot fi folosite şi tehnici de imunofluorescență. Diagnosticul etiologic este important mai ales în cazul infectiilor cu SARS pentru urmărirea evoluției epidemiei şi limitarea extinderii infecției în populație. (33)

\section{Tratament}

Tratamentul este în principal suportiv. Studiile in vitro arată efecte promițătoare ale clorochinei asupra coronavirusurilor însă este nevoie de studii clinice pentru a confirma rezultatele. În acest moment nu există vaccin aprobat pentru infecția cu coronavirus. $(33,40)$.

\section{RINOVIRUSUL C}

Rinovirusul este virusul implicat cel mai frecvent în infecțiile respiratorii acute ale adultului şi copilului, copilul fiind rezervorul principal al infecției. 30-50\% dintre infecțiile de tract superior sunt cauzate de rinovirus. (41). Rinovirusurile fac parte din familia Picornaviridae, fiind descrise trei tipuri principale HRV-A, HRV-B, HRV-C acestea având peste 100 de serotipuri. Rinovirusul C este descoperit cel mai recent, în anul 2007, fiind un virus ubicuitar, cu efecte asemănătoare speciilor A şi $\mathrm{B}$, însă implicat mai frecvent în exacerbările severe de astm şi bronşiolitele complicate ale sugarului şi copilului (42). Acesta prezintă genomul diferit faţă de speciile A şi B, creşte greu pe mediile de cultură, iar receptorul de care se ataşează este încă necunoscut, însă diferit de ICAM1. El nu răspunde la Pleconaril, un antiviral ceea a fost eficient împotriva speciei A. $(41,43)$

Este întâlnit pe toată perioada anului, însă cu vârf de incidenţă toamna şi iarna, studiile recente arată că este specia de rinovirus cel mai frecent întâlnită, fiind responsabilă de aproape jumătate din infecțiile cu rinovirus. Modul de transmitere este cel mai frecvent prin inocularea secrețiilor infectate la nivelul nasului şi conjunctivelor, contagiozitatea fiind maximă în primele 5 zile. $(44,45)$ $(46,47)$

\section{Manifestările clinice}

La fel ca HRV-A şi HRV-B, rhinovirusul C este implicat cel mai frecvent în infecțiile de tract respirator superior atât la adult, cât şi la copil, fiind descris ca agent etiologic în otitele şi sinuzitele acute ale copilului. S-a constatat că aproximativ jumătate din exacerbările de astm ale copilului sunt determinate de infecții virale, iar rhinovirusul este implicat în $50 \%$ dintre acestea. În mod specific, rhinovirusul $C$ este implicat în exacerbări severe de astm, bronşiolite severe şi în cazurile de wheezing recurent mai frecvent decât celelalte două specii, iar studii recente îl implică pe acesta ca agent cauzal în apneea sugarului şi nou-născutului (ALTE-Apparently Life-Threatening Events) (48-51). HRV-C poate cauza şi infecții extrarespiratorii fiind izolat din plasma, scaunul şi lichidul pericardic al unui copil de 14 luni cu pneumonie severă şi pericardită (52). Deşi în trecut erau considerate a fi virusuri implicate doar în infecții uşoare şi autolimitate cu impact minim asupra sănătății individului, odată cu descoperirea HRV-C studiile demonstrează ca rolul acestora este chiar mai important decât al VSR în infecțiile de tract respirator inferior al copilului ce necesită spitalizare, în declanşarea exacerbărilor severe de astm bronşic şi în wheezingul recurent al copilului. $(49,53,54)$

\section{Tratament}

Tratamentul este suportiv, $\mathrm{HRV}-\mathrm{C}$ nu a răspuns la pleconaril, un antiviral eficient împotriva HRV-A. (41) 


\section{CONCLUZII}

Infecțiile respiratorii acute reprezintă în continuare una din cauzele principale de mortalitate infantilă în întreaga lume. Datele noi ce continuă să apară despre virusurile recent descoperite sunt promițătoare pentru îțelegerea diversității genetice, a mecanismelor de acțiune, a modului de apărare şi răspuns a organismului uman. Cunoaşterea profilurilor clinico-epidemiologice contribuie la elabo- rarea diagnosticului corect şi orientarea terapeutică individualizată în infecțiile virale ale tractului respirator inferior la copil.

Mențiune: Această lucrare este efectuată în cadrul Programului Operațional Sectorial pentru Dezvoltarea Resurselor Umane (POSDRU), finanțat din Fondul Social European şi Guvernul României prin contractul nr: POSDRU/159/1.5/ S/137390. 